\section{X-Ray Crystal Data on Some Methyl-Pentofuranosides}

SVEN FURBERG and HANS HAMMER

\author{
Institute of Chemistry, University of Oslo, \\ Blindern-Oslo, Norway
}

A great deal of information on the conformations of pyranose sugars has been collected during latter years and the structure of several of these compounds has been determined by X-ray crystallographic methods ${ }^{1,2}$. Much less is known about the furanose structures of the sugars and we thought it therefore of interest to examine a simple compound of this type in detail. In this note the unit cell dimensions and space groups of five methyl pentofuranosides are reported.

The compounds were prepared by Professor Dr. E. Berner and collaborators ${ }^{3,4}$, whom we would like to thank for placing samples at our disposal. The unit cell dimensions (which are accurate to about $0.5 \%$ ) were derived from oscillation and Weissenberg diagrams taken with $\mathrm{Cu} K a$ radiation $(\lambda=1.542 \AA)$. The space groups were determined from systematic absences, taking also into account that the substances are optically active. Densities were measured by flotation in mixtures of carbon tetrachloride and benzene.

Methyl $\beta$-ribofuranoside, m.p. $80^{\circ} \mathrm{C}$, specific rotation in water $[a]^{20} \mathrm{D}=-49.8^{\circ}$. The compound crystallizes from ethyl acetate in well-developed crystals elongated along $c$, bounded by $\{100\}$ and $\{010\}$. They are orthorhombic, with unit cell dimensions $a=12.87 \AA, b=24.07 \AA$ and $c=4.86 \AA$. Reflexions $h 00,0 k 0$ and $00 l$ are absent for odd values of the indices, and the space group is $P 2_{1} 2_{1} 2_{1}$. The density was found to be $1.43 \mathrm{~g} \cdot \mathrm{cm}^{-3}$, and there are eight (calc. 7.90 ) molecules in the unit cell. The asymmetric unit in the crystal thus consists of two molecules.

Methyl a-xylofuranoside, m.p. $84^{\circ} \mathrm{C}$, $[a]^{20} \mathrm{D}=+182^{\circ}$. The crystals are monoclinic, elongated along $c$, with cell dimensions $a=8.81 \AA, b=8.11 \AA, c=6.24 \AA$ and $\beta=123^{\circ}$. The space group is $P 2_{1}$. The measured density of $1.43 \mathrm{~g} \cdot \mathrm{cm}^{-3}$ corresponds to two (calc. 1.96) molecules in the unit cell.
The reflexion $20 \overline{\mathrm{I}}$ is by far the strongest one in the hol zone and the molecules are probably lying roughly in these planes.

Methyl a-arabofuranoside, m.p. $51^{\circ} \mathrm{C}$, $[a]^{20}{ }_{D}=+126^{\circ}$. The crystals are very hygroscopic and were kept in glass capilla. ries during the examination. They were needle- or rod-shaped, in general poorly developed, and showed straight extinction, or nearly so, under the polarizing microscope. The diagrams obtained were rather poor, but indicated that the crystals probably are triclinic (pseudo-monoclinic). Space group $P 1$. The following lattice parameters were derived: $\bar{d}_{100}=12.09 \AA$, $b=6.87 \AA, c=4.61 \AA, \beta=100^{\circ}, \gamma=93^{\circ}$. Two molecules in the unit cell correspond to a density of $1.42 \mathrm{~g} \cdot \mathrm{cm}^{-8}$. This value is somewhat smaller than those of the other three simple pentofuranosides, for which values $1.45-1.46 \mathrm{~g} \cdot \mathrm{cm}^{-3}$ are calculated. The melting point is also lower.

Methyl a-lyxofuranoside, m.p. $\quad 97^{\circ} \mathrm{C}$, $[a]^{20} \mathrm{D}=+129^{\circ}$. The crystals were needleshaped, elongated along $c$, with forms $\{100\}$ and $\{010\}$ developed. The cell dimen. sions are $a=10.34 \AA, b=15.56 \AA$ and $c=4.63 \AA$ and the space group is $P 2_{1} 2_{1} 2_{1}$. The density calculated on the basis of four molecules per unit cell is $1.46 \mathrm{~g} \cdot \mathrm{cm}^{-3}$.

Methyl a-fucofuranoside, m.p. $126^{\circ} \mathrm{C}$, $[a]^{20} \mathrm{D}=-111.4^{\circ}$. The crystals occur either as nicely developed pyramids or as needles. They are trigonal, with space group $P 3_{1}$, and cell dimensions $a=b=9.21 \AA$ and $c=8.98 \AA$. The density was found to be $1.33 \mathrm{~g} \cdot \mathrm{cm}^{-3}$ and there are three (calc. 2.97 ) molecules in the unit cell.

Discussion. The unit cell dimensions and space groups of a great number of sugar derivatives have been determined by Cox ${ }^{5}$. $\mathrm{He}$ found that one of the axes frequently had a length of about 4.5 $\AA$, indicating a molecular "thickness" of this order of magnitude, with the ring "plane" roughly perpendicular to the short axis. As will be seen, three of the compounds described above have an axis of this type.

Amongst the compounds studied, the lyxoside derivative clearly is the most suitable one for a detailed structure analysis. We have collected three-dimensional intensity data, and tried to solve the structure by Patterson syntheses, inequalitites and other methods, but so far without success. We believe that the "centre" of the molecule lies in the neighbourhood of 
either $(0,1 / 4,1 / 4)$ or $(1 / 4,0,0)$. The Patterson syntheses show that there are layers of molecules c/2 apart approximately parallel to the $a b$-plane. Correspondingly, the 002 reflexion is extremely strong. It is interesting that the corresponding hexose sugar, methyl a-mannofuranoside, has the same space group and very similar unit cell dimensions, namely 4.64 $\AA, 11.73 \AA$ and $15.87 \AA$. These two sugars have the same furanose configuration, the mannoside being derived by substituting a hydrogen at $\mathrm{C}_{5}$ in the lyxoside with $-\mathrm{CH}_{2} \mathrm{OH}$. This increases the length of the $a$ axis from 10.34 $\AA$ to $11.73 \AA$, whereas the other axes remain nearly unchanged. This indicates, as is seen from models, that the methyl lyxoside molecule is most extended in the direction of $b$.

Further attempts to solve the structure are being carried out.

1. McDonald, T. R. R. and Beevers, C. A. Acta Cryst. 5 (1952) 654.

2. Hordvik, A. Acta Chem. Scand. 15 (1961) 16.

3. Augestad, I. and Berner, E. Acta Chem. Scand. 8 (1954) 251

4. Augestad, I. and Berner, E. Acta Chem. Scand. 10 (1956) 911.

5. Cox, E. G., Goodwin, T. H. and Wagstaff, A. I. J. Chem. Soc. 19351495.

6. Cox, E. G. and Goodwin, T. H. J. Chem. Soc. 19321844.

Received June 28, 1961.

\section{The Structures of Widdrol $*$ and} the Alcohol, $\mathrm{C}_{15} \mathrm{H}_{26} \mathrm{O}_{2}$, Isolated from Widdringtonia juniperoides (L.) Endl. C. E N Z E L L

Organisk-kemiska Institutionen, Kungl. Tekniska Högskolan, Stockholm, Sweden

Frdtman and Thomas ${ }^{1}$ isolated the sesqui-

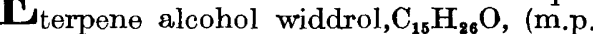
$98^{\circ}$ ) and a further alcohol, $\mathrm{C}_{15} \mathrm{H}_{28} \mathrm{O}_{2}$, (m.p. $\left.154^{\circ} ;[a]_{\mathrm{D}}-9^{\circ}\right)$ from the heartwood of

* Presented by H. Erdtman at the Chemical Society symposium on terpene chemistry in London (23.2.1961). Proc. Chem. Soc. 1961 129.

Acta Chem. Scand. 15 (1961) No. 5
Widdringtonia species. These authors suggested that widdrol was a dicyclic, tertiary alcohol containing one double bond and they obtained 1,7-dimethyl-4-isopropylnaphthalene (1) on selenium dehydrogena. tion. Recently Nagahama ${ }^{2}$ has shown that widdrol is formed on hydration of thujopsene ${ }^{3}(2)$ with oxalic acid. The following experimental evidence shows that widdrol has structure (3).<smiles>Cc1ccc2c(C(C)C)ccc(C)c2c1</smiles>

1<smiles>CC1(C)CCCC2(C)CCC(C)(O)C(CO)OC12</smiles>

4<smiles>CC12CCCC=C1C(C)(C)C(=O)CC2</smiles>

7<smiles>CC(=O)CCC1C(C)(C)CCCC1(C)CC(=O)O</smiles>

10

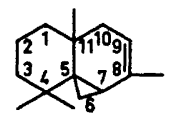

2<smiles>CC12CCCCC(C)(CC1)C(C)(O)CC2</smiles>

5

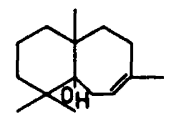

8

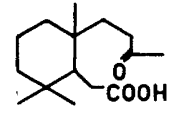

II
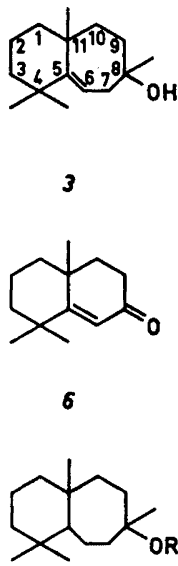

9 a R H

Ib R Ac<smiles>CC1(C)CCCC2(C)C3(C)CCC(Br)(CC3)C12Br</smiles>

12
Widdrol [I.R.: $v \max _{\max }^{\mathrm{CHBr}_{3}} 839,1635 \mathrm{~cm}^{-1}$; PMR: $\left.\tau 4.50\left(\mathrm{CR}_{2}=\mathrm{CRH}\right)\right]$ on ozonolysis, followed by reduction with lithium aluminium hydride, gave a triol (4) (m.p. 97$98^{\circ}$ ) together with minor amounts of an epoxyalcohol (5) (m.p. $153-154^{\circ}$ ).

The triol (4) on oxidation (chromium trioxide-sulphuric acid-acetone) furnished a hydroxyketoaldehyde $\left(v_{\max }^{\mathrm{CCl}_{4}} 2720\right.$, $1717,1690 \mathrm{~cm}^{-1}$ ), which on treatment with alkali yielded an $a, \beta$-unsaturated ketone (6) $[\lambda \underset{\max }{\text { EtoH }} 240 \mathrm{~m} \mu(\varepsilon 13000) ; 2,4$-dinitrophenylhydrazone m.p. 204-205 ${ }^{\circ}$ and acetaldehyde. The DL-octalone (6) was synthesised from the ketone (7) by Huang. 